\title{
Spesialopplærte \\ sykepleiere hjelper \\ sårbare \\ førstegangsforeldre
}

Førstegangsforeldre som har utfordringer, kan få hjelp av familiesykepleiere. De bes $\varnothing$ ker familiene hjemme, fra kvinnen er gravid til barnet er to år. Det kan bidra til at barnevernet ikke behøver å gripe inn. 
Filip Drozd

Forsker

Seksjon for sped- og småbarn, Regionsenter for barn og unges psykiske helse, Helseregion øst og sør

Hans Bugge Bergsund

Seniorrådgiver

Seksjon for sped- og småbarn, Regionsenter for barn og unges psykiske helse, Helseregion øst og sør

Kristin Lund

Seniorrådgiver

Seksjon for Nurse-Family Partnership, Regionsenter for barn og unges psykiske helse,

Helseregion øst og sør

Marit Bergum Hansen

Seniorkonsulent

Regionsenter for barn og unges psykiske helse, Helseregion øst og sør

Marte Dalane-Hval

Forskningskoordinator

Seksjon for sped- og småbarn, Regionsenter for barn og unges psykiske helse, Helseregion øst og sør

Tine Gammelgaard Aaserud

Seksjonsleder og fagsjef

Seksjon for Nurse-Family Partnership, Regionsenter for barn og unges psykiske helse, Helseregion øst og sør

Forebygging hjemmebesøk graviditet spebarn Nurse-Family Partnership

Sykepleien 2020108 (79674) (e-79674)

DOI: 10.4220/Sykepleiens.2020.79674

\section{Hovedbudskap}

«Familie for første gang» er et evidensbasert program utviklet i USA for å hjelpe og støtte sårbare førstegangsforeldre. Målet er å sikre gode svangerskap, fremme barnets helse og utvikling og bedre familiens livssituasjon. Hensikten med artikkelen er å dele erfaringer med å innføre programmet i Norge. 
Sped- og småbarn som blir utsatt for omsorgssvikt, tenderer til å få vansker og en skjevutvikling som videreføres i generasjoner. Mange av disse barna oppdages ikke eller blir ikke fanget opp før det er for sent å hjelpe dem. Foreldrene til en del av barna har utfordringer som fattigdom, egenerfaring fra barnevern og rusproblematikk.

Tidlig hjelp vil gjøre det mulig å forebygge slike problemer og unngå omsorgsovertakelse på grunn av manglende omsorgsevne hos foreldrene. Dette var bakgrunnen for en gryende interesse for «Familie for første gang» (Nurse-Family Partnership, NFP) som oppsto i forskermiljøet i Norge allerede på 9o-tallet.

\section{Hva er en familiesykepleier?}

Familiesykepleier er ikke en formelt anerkjent tittel, men brukes som betegnelse for dem som følger opp familiene i programmet. I «Familie for første gang» er det ansatt helsesykepleiere og jordmødre som har fått omfattende opplæring. Fellesbetegnelsen familiesykepleiere er kun benyttet for enkelthets skyld og fordi helsesykepleiere og jordmødre utfører de samme oppgavene. Samme betegnelse brukes i de fleste land som har Nurse-Family Partnership.

\section{Flere hadde behov for hjelp}

I 2012 kom en studie om sped- og småbarn i barnevernsregisteret (1). Den viste at antallet sped- og småbarn i barnevernet økte med 22 prosent fra 1995 til 2008, og at manglende omsorgsevne var den vanligste grunnen for tiltak. Vel en tredjedel av sped- og småbarna hadde vært utsatt for omsorgssvikt. Det var vanligst i familier som mottok sosialhjelp, når mor var ugift og hadde lite utdanning og i familier med bare ett barn.

\section{$\equiv \ll$ Manglende omsorgsevne var den vanligste grunnen for tiltak.»}

For gruppen med barn mellom 13 og 18 år med tiltak i barnevernet i 2008, fikk nesten 70 prosent omsorg utenfor hjemmet. Svært mange av de yngste barna i barnevernet risikerte dermed å bli plassert i fosterhjem eller barnevernsinstitusjoner med tiden, dersom de ikke fikk tilstrekkelig hjelp. 
Samtidig var tiltakene som ble satt inn når barna var små, dominert av velferdstiltak. Systematisk oppfølging over tid, med hjelp til foreldre og felles oppmerksomhet på barnas behov for utviklingsst $\varnothing t t e$, fantes ikke i barnevernsstatistikken den gang.

\section{Forklaring på forkortelsene}

BFD: Barne- og familiedepartementet

Bufdir: Barne-, ungdoms- og familiedirektoratet

BUP: Barne- og ungdomspsykiatrisk poliklinikk

DANCE: Dyadic Assessment of Naturalistic Caregiver Child Experiences. Måleinstrument for observasjon.

EAS: Emotional Availability Scales. Observasjonsmål som ser på kvaliteten av foreldre-barn samspill.

Marte Meo/VIPI: Videofeedback of Infant-Parent Interaction. Systematisk samspillsveiledning for foreldre.

NBO: Newborn Behavioral Observation, Nyfødt observasjon. Metode for å observere spedbarn mellom o-3 måneder.

NFP: Familie for første gang (Nurse-Family Partnership)

NUBU: Nasjonalt utviklingssenter for barn og unge

RBUP: Regionsenter for barn og unges psykiske helse

\section{Slik var oppstarten i Norge}

Regionsenter for barn og unges psykiske helse (RBUP), Helseregion Øst og Sør og Nasjonalt utviklingssenter for barn og unge (NUBU) etablerte i 2013 en prosjektgruppe som fikk i mandat å utrede muligheten for å finne strukturerte, evidensst $\varnothing$ ttede hjemmebaserte programmer som kunne supplere det ordinære tjenestetilbudet gjennom oppfølging av sped- og småbarn i utsatte familier over tid (2). Det ble også opprettet kontakt med Barne- og familiedepartementet

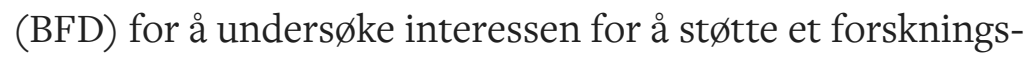
og implementeringsprosjekt.

Som ledd i arbeidet ble det gjennomført en studietur til England og Skottland. Der hadde de allerede tatt i bruk NFP. I tillegg til prosjektgruppen deltok daværende statsråd og avdelingsdirekt $\varnothing$ rer fra BFD og Barne-, ungdoms- og familiedirektoratet (Bufdir).

I 2014 ble det bevilget midler over statsbudsjettet til NFP og arbeidet med å få NFP på plass ble satt i gang. Høsten 2015 ble det sendt ut invitasjoner til kommuner, og det ble oppstart i samarbeid med de to utprøvingsområdene i Rogaland (Stavanger, Sandnes og Time kommuner) og i Oslo (Bydel Gamle Oslo og Bydel Søndre Nordstrand). 


\section{De første familiene fikk hjelp i 2016}

Det ble ansatt et team i hvert utprøvingsområde bestående av en teamleder og veileder, fire familiesykepleiere (jordm $\varnothing \mathrm{dre}$ og helsesykepleiere) og en sekretær. Alle ansatte fikk opplæring i NFP-programmet og i relevante verktøy. I august 2016 begynte vi å rekruttere familier til programmet.

I dag er NFP forankret i regjeringens handlingsplaner mot vold og overgrep mot barn, barnefattigdom og rusproblematikk (3-5). NFP retter seg mot familier som befinner seg i en vanskelig livssituasjon med $\varnothing \mathrm{kt}$ risiko for omsorgssvikt. Bufdir har den norske lisensen for NFP, mens RBUP er programansvarlig på vegne av Bufdir.

\section{Hva er «Familie for første gang»?}

NFP er et hjemmebasert program for førstegangsforeldre som har en utfordrende livssituasjon. Programmet er utviklet i USA av professor David Olds ved University of Colorado, gjennom snart 40 år. NFP brukes i 44 stater i USA, samt i Canada, Australia, Bulgaria, Skottland, Nord-Irland og England. Programmet testes også ut i Bulgaria.

I Norge er NFP under utprøving med mer enn 150 familier. Deltakelse innebærer at familien 1) frivillig mottar 2) hjemmebes $\varnothing \mathrm{k}$ av en 3) familiesykepleier, fra graviditet og frem til barnet fyller to år (opptil 64 hjemmebes $\varnothing \mathrm{k}$ ). Dette utgjør tre av de viktigste av i alt 14 kjerneelementer i NFP. Elementene beskriver de strukturene som skal anvendes i praksis for å sikre gode resultater i arbeidet med familiene (6).

\section{三 «Hensikten med programmet er å fremme sunne svangerskap, forbedre oppvekstvilkårene for barn og styrke foreldrenes livsforløp.»}

Hensikten med programmet er å fremme sunne svangerskap, forbedre oppvekstvilkårene for barn og styrke foreldrenes videre livsforløp. Det ligger klare føringer for hva som skal gjennomgås under hjemmebesøkene. Vi er samtidig opptatt av å ta utgangspunkt i hva familien $\varnothing$ nsker å jobbe med. 
NFP bygger på et hovedprinsipp om å styrke foreldres $\varnothing$ nske om å beskytte barna og gjøre det beste for sine barn. Teoriene som utgjør grunnlaget for NFP er $\varnothing$ kologisk teori om de sosiale systemer og kontekster rundt mor og barn (7), tilknytningsteori (8) og sosial læringsteori (9). Den terapeutiske relasjonen som utvikles mellom foreldrene og familiesykepleieren, fremstår som en av grunnpilarene i NFP.

\section{Forskning viser at NFP virker}

Det er gjennomført sju randomiserte kontrollerte studier i tre ulike land (fem i USA, én i Nederland og én i England), samt at programmet også evalueres og kvalitetssikres i utprøvingsfasen i de ulike landene for nasjonal tilpasning og gjennomførbarhet, deriblant Norge.

Samlet sett har NFP vist å ha en effekt på minst 21 ulike utfallsmål. Det har blant annet ført til redusert barnedødelighet, rusmiddelbruk og barnemishandling (10, 11). Studiene som er gjennomført av programutviklerne i USA kan også vise til virkninger opptil 20 år etter programgjennomføring, blant annet på barnas utdanning og bruk av velferdstjenester (12).

\section{$\equiv$ ¿NFP er et kostnadseffektivt program som beriker livene til familiene.»}

Basert på samfunns $\varnothing$ konomiske beregninger konkluderte Miller (10) at NFP er et kostnadseffektivt program som beriker livene til familiene, og er samfunnsnyttig i form av å redusere kriminalitet og velferdsutgifter.

\section{NFP blir implementert i fire faser}

Internasjonal implementering av NFP består av fire faser:

1. Tilpasninger av NFP i en nasjonal kontekst.

2. Programimplementering med følgeevaluering av gjennomførbarhet.

3. En effektstudie.

4. Storskala implementering.

Implementering forstås her som aktiviteter som har til hensikt å innføre og ta i bruk en bestemt metode eller et program i praksis, slik som for eksempel opplæring, veiledning, datainnsamling og analyse, og koordinering og samarbeid med andre tjenester. 


\section{Programmet ble tilpasset norske forhold}

Da BFD bevilget midler til NFP handlet den første oppgaven i stor grad om tilpasning av målgruppen og valg av utprøvningsområde. Siden Norge har et lavt innbyggertall, få tenåringsgraviditeter og er et langstrakt land, i kombinasjon med at forekomsten av alkoholbruk, tobakksrøyking og vold i nære relasjoner i graviditeten er lav, men like fullt utgjør en alvorlig risiko for mor og barn, var det nødvendig å utrede om det var behov for tilpasninger av målgruppe for NFP i Norge.

I utredningen ble det foreslått å bruke en totrinnsmodell tilsvarende modellen som ble benyttet i Nederland, for identifisering og inklusjon av deltakerfamilier (13). Dette ble også innført i Norge.

\section{Gravide ble invitert til å delta}

Med bakgrunn i rapporten besluttet vi følgende modell for rekruttering av gravide kvinner: Trinn 1 hvor jordm $\varnothing$ dre, fastleger og andre tjenester som treffer gravide kan invitere dem til å ta kontakt med «Familie for første gang». Kriteriene her er at det er frivillig, det må være første planlagte gjennomføring av svangerskap, innen svangerskapsuke $28 \mathrm{og}$ kvinnen må bo i rekrutteringsområdet.

Det er typisk jordmødre ved helsestasjonstjenesten som har en profesjonell bekymring for svangerskapet og/eller det forestående foreldreskapet, som henviser og inviterer kvinnen. Fastleger, barnevernstjenesten, DPS, Nav og andre tjenester kan henvise kvinnen til NFP-teamene, og kvinnen selv kan også ta kontakt.

\section{三 «Våre erfaringer med bruk av totrinnsmodellen for rekruttering er udelt positive.»}

Våre erfaringer med bruk av totrinnsmodellen for rekruttering er udelt positive. Ved å gå flere runder før inklusjon, får både vi og familiene mulighet til å bli kjent, tenkt oss om og vurdert om dette er et egnet tilbud til familien. Et omfattende program som NFP er ikke hensiktsmessig for alle. Gjennom totrinnsmodellen søker vi å finne de som vil ha nytte av en slik intervensjon. 


\section{Hvem får hjelp?}

I inntakssamtalen, trinn 2, må minst en av følgende risikofaktorer være til stede for at den gravide skal bli inkludert i programmet:

1. De må ha erfaringer med vold/overgrep i hjemmet.

2. Den gravide må ha utfordrende erfaringer fra egen oppvekst (omsorgssvikt, barnevern).

3. Det må være lite sosial støtte og/eller alvorlige konflikter mellom de vordende foreldre.

4. Det må forekomme psykiske helseproblemer hos de vordende foreldre.

5. De kommende foreldrene er ikke i arbeid, opplæring eller utdanning, og de har lavt utdanningsnivå.

Vi vurderer i tillegg om familien har vedvarende lav inntekt og vanskelig økonomi, om familien består av en enefors $\varnothing$ rger som er avhengig av sosial stønad, og vi etterspør familiens bruk av tobakk og rusmidler.

\section{Opplæring av familiesykepleiere}

Opplæringen i NFP består av tre moduler; graviditet, spedbarnsfasen ( $0-1$ år) og småbarnsfasen (1-2 år). Helsesykepleierne og jordm ødrene får fem dagers opplæring i hver modul, som ledes av nasjonal fagsjef og seniorrådgiver, og som er tilpasset til norsk kontekst.

For sårbare familier vil læring som kun er basert på samtale og refleksjon sjelden være tilstrekkelig. De trenger å være sammen med og lære gjennom direkte observasjon, for å forstå hva spedbarnet trenger for god utvikling. Et viktig grunnlag for å få til dette samarbeidet, er derfor relasjonen som utvikles mellom familien og familiesykepleier, noe som så langt, fremheves av så å si alle mødrene i NFP.

Familiesykepleier er ikke en formelt anerkjent tittel, men brukes i NFP-programmet som betegnelse på de sykepleierne som utøver oppfølging av sårbare familier.

\section{Veiledning av familiene}


I NFP internasjonalt benyttes måleinstrumentet Dyadic Assessment of Naturalistic Caregiver Child Experiences (DANCE) for observasjon av samspillet mellom mor og barn, fra første levemåned og til barnet fyller to år.

Familiesykepleier observerer og identifiserer styrker og svakheter i samspillet og benytter dette i veiledningen.

Ved innføringen av NFP i Norge ble vi oppfordret til å vurdere andre metoder for samspillsvurdering, fordi DANCE ikke er et måleinstrument som benyttes utenfor NFP, noe som vanskeliggjør sammenlikning med oppfølgingsprogram av liknende art, og fordi opplæringen er omfattende og krever godkjente instruktører som vi ikke har i Norge. Vårt mål med utvikling og tilpasning til norsk kontekst har vært å benytte metoder som allerede er i bruk i Norge, og hvor vi har gode muligheter for opplæring og veiledning. Derfor hentet vi inn metoder som Nyfødt observasjon, videoveiledning og Emotional Availability Scales.

\section{Lærer å observere foreldrene}

Metoden Nyfødt observasjon (Newborn Behavioral Observation, NBO) (14) gir en teoretisk og praktisk kunnskap om tidlig utviklingspsykologi, foreldresamarbeid og veiledning. Familiesykepleierne gjennomgår en seks måneder opplæring med sertifisering (15).

\section{三 «Foreldrene skal få nødvendig støtte til å bli kjent med den nyfødte.»}

I NFP gjennomføres NBO ved de fire første hjemmebes $\varnothing$ kene. Hensikten med å benytte NBO er at foreldrene skal få nødvendig støtte i å bli kjent med den nyfødte og hjelp til å tolke babyens signaler og behov. NBO likner DANCE i den forstand at de begge er metoder for observasjon.

I Norge er det utdannet NBO-observatører ved flere institusjoner (sykehus, helsestasjoner, psykisk helsetjeneste, BUP). Så metoden er godt kjent og det er skapt grunnlag for en unik felles plattform for forståelse av nyfødte, og et felles begrepsapparat. Mødre har beskrevet den nye kunnskapen om barnet sitt som nyttig, og at alle burde ha muligheten til å få så god hjelp når de får barn for første gang.

Fordi NBO ikke strekker seg over to år som DANCE gjør, har vi valgt å tilby videoveiledning med utgangspunkt i prinsippene i Marte Meo fra tre til seksmåneders alder. Det har ikke vært vanlig å benytte video i samspillsveiledningen i NFP, så her fremstår Norge som et foregangsland. 


\section{Hva er Marte Meo?}

Marte Meo er en veiledningsmetode utviklet av Maria Aarts i Nederland for 25 år siden. Metoden har spredd seg internasjonalt. Det er til i dag utviklet programmer innenfor 19 fagområder fra premature babyer til aldersdemente. Metoden har vært brukt i Norge siden 1990 og har i hovedsak vært brukt for å styrke og utvikle samspillet mellom foreldre og barn.

Kilde: Marte Meo foreningen

\section{Foreldrene lærer om samspill}

Videofeedback of Infant-Parent Interaction (VIPI) er en systematisk samspillsoppfølging med bruk av video som familiesykepleierne tilbyr familiene i løpet av barnets første leveår, og til dem som ønsker mer når barnet er 12 og 18 måneder (16).

I oppfølgingen tilrettelegges for systematisk bruk av stillbilder og filmklipp med utgangspunkt i barnets behov. Dette gjøres gjennom opptak av foreldre-barn-samspill med utgangspunkt i for eksempel barnets initiativ til kontakt og behov for pause, og som analyseres før veiledning med familien.

Tilbakemeldingene i veiledning retter seg mot å styrke foreldrenes opplevelse av barnets behov for st $\varnothing t t e$ i sin utvikling. Familiesykepleierne gjennomgår 3+2-dagers opplæring fra et nasjonalt NFP-kontor. Familiesykepleierne har jevnlige oppfølgingsdager i tillegg til veiledning i gruppe og individuell veiledning ved behov.

\section{三 «Mor, og ofte også far, får anledning til å se seg selv i samspill med barnet.»}

Det unike med VIPI er at familiesykepleierne tar utgangspunkt i det de ser på filmen i den aktuelle familien, og forstørrer de utviklingsfremmende handlingene mellom foreldrene og barnet, og oppmuntrer foreldrene til å gjøre mer av det som fungerer bra. Mor, og ofte også far, får anledning til å se seg selv i samspill med barnet og reflektere sammen med familiesykepleier rundt hva som skjer på filmen og hva barnet trenger av utviklingsst $\varnothing$ tte fra sine omsorgspersoner. 


\section{Hvordan blir samspillet vurdert?}

I Norge har vi valgt å benytte Emotional Availability Scales

(EAS) for å vurdere samspillet mellom foreldre og barn (17) hvor familiesykepleier gjør et 20 minutters ustrukturert filmopptak av mor og barn ved tre tidspunkt. Filmene kodes av eksterne kodere. Det ses som en styrke at vurderingen blir utført av kodere som ikke kjenner familien med tanke på objektivitet.

Kodingssystemet dekker seks dimensjoner i samspillet hvorav fire av dimensjonene handler om foreldrenes bidrag, for eksempel deres evne til å strukturere samspillet og i hvilken grad de er avventende eller påtrengende i samspillet. To av dimensjonene er opptatt av barnets bidrag, det vil si barnets respons på omsorgsgiver og initiativ til samspill med omsorgsgiver. Formålet er at familiesykepleieren skal kunne vurdere emosjonell tilgjengelighet i samspillet mellom mor og barn over tid og planlegge videre arbeid i samspillsveiledningen.

\section{Evaluering av «Familie for første gang»}

I tillegg til at forskningskoordinator gjør kontinuerlige dataanalyser i den daglige driften i NFP, er det gjennomf ørt en utredning av fremtidig organisering og samfunnsøkonomiske beregninger av NFP, og det er en pågående og uavhengig følgeevaluering som utføres av Oslomet.

På nåværende tidspunkt er familiesykepleiere, sekretærer og det nasjonale NFP-kontoret ansatt ved RBUP, men i utredningen av fremtidig organisering kommer det frem at det vil være mest hensiktsmessig med kommunal ansettelse av teamene med tilknytning til helsestasjonene for å sikre lokal forankring, erfaring og læring.

Siden NFP er et målrettet program mot et mindre antall sårbare familier, vil det være behov for interkommunalt samarbeid for å dekke mindre tettbygde strøk (18). For kommunene vil det innebære et ansvar for å etterleve lisenskravene med st $\varnothing$ tte av det nasjonale NFP-kontoret.

Av flere årsaker foreslås det av Lippestad og medarbeidere (18) å beholde et nasjonalt kontor som vil ha et overordnet ansvar for kvalitetssikring av faglig innhold, utvikling og implementering. En tilsvarende sentermodell har vist seg nyttig i Norge tidligere (19), og bør gi gode forutsetninger for vellykket implementering. 


\section{Lønnsomt for samfunnet}

Forenklede samfunns $\varnothing$ konomiske beregninger viser en gjennomsnittlig brutto besparelse av unngåtte eller utsatte omsorgsovertakelser på 151000 kroner per familie, for hele programperioden fra svangerskapet til barnet fyller to år, med kostnadsnivået for 2018 (20). For utsatte eller unngåtte omsorgsovertakelser er de totale kostnadsbesparelsene beregnet til 150500 kroner per familie for kommunene. Og ifølge foreløpige resultater fra følgeevalueringen trekker familiesykepleierne frem at oppfølgingen av deltakere gjennom NFP sannsynligvis har forebygget omsorgsovertakelser (21).

Tilbakemeldinger fra barnevernet i utprøvingsområdet Rogaland skisserer at de henlegger flere barnevernssaker der NFP er inne. De beskriver i tillegg et godt og hensiktsmessig samarbeid i saker hvor begge parter er involvert.

\section{«De henlegger flere barnevernssaker der NFP er inne.»}

Følgeevalueringen tyder så langt på at det er et behov for NFP, sett opp mot andre tiltak og tilbud (22). Programmet har god politisk og faglig st $\varnothing t t e$, og deltakere trekker frem verdien av den oppfølgingen de mottar, og at denne oppfølgingen er annerledes enn annen støtte de făr.

\section{Stor arbeidsbelastning for sykepleierne}

Familiesykepleierne er begeistret for arbeidet, men med innføringen av et fagutviklingsprosjekt som NFP følger en stor arbeidsbelastning og et ansvar knyttet til å få på plass rammene og strukturene for programmet. Dette gjelder blant annet all opplæring og veiledning i NFP og utfordringer med gjennomf $\varnothing$ ringen av videoveiledning og videoobservasjoner knyttet til samspillsvurdering (22).

I følgeevalueringen kommer det også frem at tilpasningen av inklusjonskriteriene til norske forhold synes å virke godt, til tross for innledende utfordringer med rekruttering og blant annet noe feilrekruttering (21). Feilrekruttering i en oppstartsfase er ikke uvanlig når familiesykepleiere og samarbeidspartnere må gjøre seg kjent med inklusjonskriteriene, og har for eksempel medført at noen deltakere er blitt inkludert i programmet etter svangerskapsuke 28 eller vist seg i ettertid å ha så store ressurser at familien klarer å benytte seg av andre velferdstjenester. 
Deltakerne er eldre med en gjennomsnittsalder på 26 år og har færre risikofaktorer enn familier i andre NFP-land.

Samtidig oppgir flere deltakere moderate til alvorlige psykiske helseplager. En effektevaluering av NFP i Norge vil derfor være svært viktig da det ikke er gitt at programmet vil ha de samme positive effektene som i tidligere studier, da de norske deltakerne skiller seg fra deltakerne i andre land.

\section{Oppsummering}

NFP er et omfattende program som krever en investering i de minste, sårbare barna for å bedre deres utvikling, helse og fremtidige livssituasjon. Investeringer gjennom tidlig innsats gir som regel størst avkastning (23).

I et livsløpsperspektiv viser amerikanske samfunns $\varnothing$ konomiske beregninger at NFP gir avkastning allerede når barna blir unge voksne, det vil si før fylte 25 år (11). Dette er i tråd med de foreløpige norske samfunns $\varnothing$ konomiske beregningene (20), og viser at det kreves en tydelig, langsiktig og forpliktende offentlig innsats og investering fra departement, direktorat, kommuner og programansvarlig for NFP i Norge.

\section{Referanser}

1. Clausen S-E, Valset K. Spedbarn og småbarn med tiltak fra barnevernet 1995-2008: Utbredelse av omsorgssvikt og risikofaktorer. Tidsskr Nor Psykologforening. 2012;49(7):6428.

2. Apeland A, Kjøbli J, Mauseth T, Vannebo UT, Slinning K. Rapport fra prosjektgruppe vedrørende Family Nurse Partnership. Oslo: Regionsenter for barn og unges psykiske helse, Helseregion $\varnothing$ st og sør og Atferdssenteret; 2013.

3. Prop. 15 S (2015-2016). Opptrappingsplanen for rusfeltet (2016-2020). Oslo: Helse- og omsorgsdepartementet; 2015.

4. Prop. 12 S (2016-2017). Opptrappingsplan mot vold og overgrep (2017-2021). Oslo: Barne- og likestillingsdepartementet; 2016.

5. Barne-, likestillings- og inkluderingsdepartementet. Barn som lever i fattigdom. Regjeringens strategi (2015-2017). Oslo: Barne-, likestillings- og inkluderingsdepartementet; 2015 . 
6. Holme H, Lund K, Aaserud TG, Hansen MB. Gode resultater med hjemmebes $\varnothing$ ksprogram. Tidsskr helses $\varnothing$ stre. 2016;(2):20-5.

7. Bronfenbrenner U. The ecology of human development: Experiments by nature and design. Cambridge: Harvard University Press; 1979.

8. Bowlby J. Attachment, Vol. 1 of Attachment and loss. New York: Basic Books; 1969.

9. Bandura A. Social learning theory. New York: General Learning Press; 1977.

10. Miller TR. Projected outcomes of nurse-family partnership home visitation during 1996-2013, USA. Prev Sci. 2015;16(6):765-77.

11. Lee S, Aos S, Drake E, Pennucci A, Miller M, Anderson L. Return on investment: Evidence-based options to improve statewide outcomes. Washington: Washington State Institute for Public Policy; 2012.

12. Eckenrode J, Campa MI, Luckey DW, Henderson Jr CR, Cole RE, Kitzman HJ, et al. Long-term effects of prenatal and infancy nurse home visitation on the life course of youths: 19year follow-up of a randomized trial. Arch Pediatr Adolesc Med. 2010;164(1):9-15.

13. Ogden T, Kjøbli J, Nærde A, Olseth A, Frønes I. Utredning om målgrupper, inklusjonskriterier og forskningsdesign for utprøving av Nurse-Family Partnership i Norge. Oslo: Atferdssenteret; 2015.

14. Nugent JK, Keefer C, Minear S, Johnson L, Blanchard Y. Understanding newborn behavior and early relationships: The newborn behavioral observations (NBO) system handbook. Baltimore: Paul H. Brookes Publishing; 2007.

15. Slinning K, Vannebo UT. The training of infant mental health practitioners: The Norway experience. Zero Three. 2015;36(1):40-5. 
16. Onsøien R, Drugli MB, Hansen MB. Videofeedback of infant-parent interaction: Manualisert intervensjon basert på Marte Meo elementene for barn o-2 år. Oslo og Trondheim: Nasjonalt kompetansenettverk for sped- og småbarns psykiske helse og Regionalt kunnskapssenter for barn og unge (RKBU-Midt); 2015.

17. Biringen Z, Derscheid D, Vliegen N, Closson L, Easterbrooks MA. Emotional availability: Theoretical background, empirical research using the EA Scales, and clinical applications. Dev Rev. 2014;34(2):114-67.

18. Lippestad JW, Pedersen E, Melby L, Kaasbøll J. Utredning av mulig framtidig organisering av Familie for første gang Nurse Family Partnership i Norge. Oslo: Sintef Teknologi og samfunn; 2018.

19. Tommeraas T, Ogden T. Is there a scale-up penalty? Testing behavioral change in the scaling up of parent management training in Norway. Adm Policy Ment Heal Serv Res. 2015;44.

20. Oslo Economics. Forventet samfunnsnytte og konsekvenser for kommunene av Familie for første gang. Oslo: Oslo Economics; 2018.

21. Pedersen E, Nilsen W. Følgeevaluering av Familie for første gang. Delrapport 2. Oslo: Arbeidsforskningsinstituttet, Oslomet; 2018. Prosjektfase 2017-2018.

22. Nilsen W, Pedersen E. Familie for første gang. Delrapport 1. Oslo: Arbeidsforskningsinstituttet, Oslomet; 2018. Oppstartsprosessen 2016-2017.

23. Heckman JJ, Masterov DV. The productivity argument for investing in young children. Rev Agric Econ. 2007;29(3):44693. 